Utah State University

DigitalCommons@USU

1992

\title{
White pine weevil response to oak overstory girdling - results from a 16-year-old study
}

\author{
S.A. Katovich
}

F.S. Morse

Follow this and additional works at: https://digitalcommons.usu.edu/aspen_bib

Part of the Forest Sciences Commons

\section{Recommended Citation}

Katovich, S. A.; Morse, F. S. 1992. White pine weevil response to oak overstory girdling - results from a 16-year-old study. Northern Journal of Applied Forestry. 9 (2): 51-54.

This Article is brought to you for free and open access by the Aspen Research at DigitalCommons@USU. It has been accepted for inclusion in Aspen Bibliography by an authorized administrator of DigitalCommons@USU. For more information, please contact

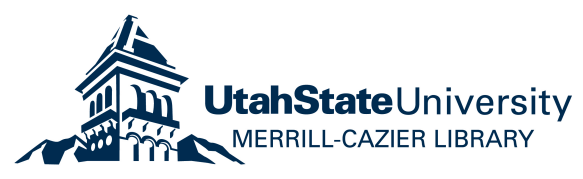


area. Because the model was developed for sandy soils, it will likely predict longer root grafting distances than occur on more loamy or clayey sites. If true, this increases the probability of disease containment and increases the number of healthy trees sacrificed (see Bruhn et al. 1991).

Public relations are crucial to program success. Directly affected property owners, persons using or moving oak products, and persons pruning or injuring oaks need to understand basic oak wilt transmission, its prevention, and the ongoing control program. Authority (for example, the Michigan Department of Agriculture) may be desirable to enforce control practices in cases where property owners with diseased trees do not want to be included in the control program. This has been necessary once in 8 years in Menominee County, MI. Available authority varies among states. Where authority is initially lacking, programs may investigate the possibility of establishing appropriate local tree ordinances.

Cutting restrictions from May to July may be necessary in the affected oak resource until all diseased trees can be sanitarily treated or disposed. The exact period for cutting restrictons should cover the period of mat production. Harvesting firewood, pruning along utility lines, or any activity which wounds residual oaks must be carefully avoided in any oak wilt area during this period.

Implementation Contracts for creating vibratory plow root graft barriers should be finalized in the winter or spring before placement. The contract should specify availability of the maximum number of hours needed and a tımeframe for completıon, allowing downtime for equipment repair, poor weather, and treatment of additional discovered epicenters. Development of contract language should be suggested by a pest management professional. To avoid confusion, actual plowing should be guided by the professional who flagged the lines.

A contact person, or persons, responsible for the program should be available throughout the year to answer questions. Letters itemizing options available to the property owner, and authorizing control treatments, should be mailed (certified) by the appropriate agency well in advance of treatment to allow feedback. Public meetings are beneficial.

Disposal of wood is generally in the form of either firewood or logs/sticks. Alternatives for proper disposal include use before April 15, thorough tarping on site until the end of the following summer, or removal to areas distant from oak resources.

Followup Once epicenters are treated, they should be visited annually to detect possible disease occurrence outside root graft barriers. The oak resource should also be monitored annually for new epicenters. Single infected trees are easily overlooked, but eventually develop pockets of mortality in areas where neighboring oaks are root grafted.

\section{LITERATURE CITED}

Bruhn, J.N., J.B. Pickens, and D.B. Stanfield 1991. Probit analysis of oak wilt transmission through root grafts in red oak stands. For. Sci. 31(1):28-44.

GarIN, G.1. 1942. Distribution of roots of certain tree species in two Connecticut soils. Conn. Agric. Exp. Stn. Bull. 454. 167 p.
Grвbs, J N 1980 Survival of Ceratocystis fagacearum in branches of trees klled by oak wilt in Minnesota. Eur. J. For. Pathol. 10:218224.

GibBS, J.N., AND D.W. French. 1980. The transmission of oak wilt. USDA For. Serv. Res. Pap. NC-185, 17 p.

GillesPIE, W.H., AND R.P. True. 1959. Three factors which influence the local spread of oak wilt in five northeastem counties of West Virginia. Plant Dis. Rep. 43:588-593.

Himelick, E.B., AND H.W. Fox. 1961. Experimental studies on control of oak wilt disease. Ill. Agric. Exp. Stn. Bull. 680:48.

JoNES, T.W. 1971. An appraisal of oak wilt control programs in Pennsylvania and West Virginia. USDA For. Serv. Res. Pap. NE-204. 15 p.

JuzwIK, J. 1983. Factors affecting overland transmission of Ceratocystis fagacearum in Minnesota. Ph.D. diss. Dep. Plant Pathol., Univ. Minn. $96 \mathrm{p}$.

JuzWIK, J., D.W. French, AND J. JeRESEK. 1985. Overland spread of the oak wilt fungus in Minnesota. J. Arboric. 11:323-327.

National Cooperative SoIl Survey. 1982. Grayling series. U.S. Soil Conserv. Survey. East Lansing, Mich.

National Cooperative Soll Survey, 1985. Pemene series. U.S. Soil Conserv. Survey. East Lansing, Mich.

SHIGo, A.L., AND Wilson, C.L. 1977. Wound dressings on red maple and American elm: Effectiveness after five years. J. Arboric. 3:81-87.

Waddell, K.L., D.D. Oswald, aNd D.S. PowELL. 1989. Forest statistics of the United States, 1987. USDA For. Serv. Resour. Bull. PNW-RB168. $106 \mathrm{p}$.

\section{ADDITIONAL REFERENCES}

French, D.W., AND T.G. Eiber. 1990. Oak wilt in Minnesota. Minn. Dep. Natur. Resour., Div. For. $28 \mathrm{p}$.

MacDonald, W.L., ANd D.F. Hindal. 1981. Life cycle and epidemiology of Ceratocystis. P. 113144 in Fungal wilt diseases of plants. Acad. Press, New York, 640 p.

ReXrode, C.O., and H.D. Brown. 1983. Oak wilt. USDA For. Serv. For. Insect \& Disease Leaflet $29.6 \mathrm{P}$.

ReXrode, C.O., AND J.R. Allison. 1981. How to identify oak wilt. USDA For. Serv. NA-GR-4.

SinclaIR, W.A., H.H. LyON, AND W.T. JohNSON. 1987. Diseases of trees and shrubs. Cornell Univ. Press, Ithaca, New York. 574 p.

\section{White Pine Weevil Response to Oak Overstory Girdling-Results from a 16-Year-Old Study}

\author{
Steven A. Katovich, USDA Forest Service, State and Private \\ Forestry, 1992 Folwell Ave., St. Paul, MN 55108; and Frank S. \\ Morse, Wisconsin DNR, Rt. 4, Box 18, Black River Falls, WI \\ 54615.
}

\begin{abstract}
${ }^{1}$ The authors wish to acknowledge the work of Knute Waggoner, Black River State Forest, Wisconsin DNR, for helping in establıshing and maintaining the treatment blocks. The authors also wish to acknowledge Arthur Hastings and Robert Ford, retred entomologists, USDA Forest Service, State and Private Forestry, for maintaining the study over the 16-year-period.
\end{abstract}

each treatment are reported for the period 1974-1979. The treatments were girdling of overstory hardwoods, predominantly oak, to produce 0, 30, 50, and $70 \mathrm{ft}^{2}$ of basal area/ac (BA) overstory and an ungirdled control of approximately 100-120 $\mathrm{ft}^{2}$ $B A$. In 1990, white pine in the 0 and $30 \mathrm{ft}^{2}$ $B A$ treatment blocks were taller and were larger in dbh than the other treatments. However, there were significantly more trees attacked by white pine weevils in the 0 and $30 \mathrm{ft}^{2} \mathrm{BA}$ treatments $(P=0.05)$. In both treatments, within 4 years of overstory removal or partial removal, mean leader diameter was sufficiently large to support weevil larvae. The $50 \mathrm{ft}^{2}$ BA treatment was intermediate in growth and number of trees attacked by weevils. In 1990, the $50 \mathrm{ft}^{2} B A$ treatment had the greatest number of unattacked dominant, codominant, and intermediate white pine per acre. Maintaining 30-50 $\mathrm{ft}^{2} \mathrm{BA}$ appeared to be an appropriate compromise be- 
tween increased growth while mitigating weevul damage.

North. J. Appl. For. 9(2):51-54.

$P_{\text {rito }}$ 1850s, white pine was considered a major forest species on approximately 14.7 million acres in Wisconsin (Curtis 1959). By 1983, the species was a major overstory component on only 225.6 thousand acres in the state (Spencer et al. 1988). Following the logging of the original pinery, two major pests, white pine blister rust, and white pine weevil, combined to reduce the forestry value of white pine. While blister rust was a newly introduced disease to North America, the white pine weevil was a native insect whose presence and damage were increased greatly in newly established plantations following logging and in open regenerated stands that originated by natural seeding of abandoned farmland.

White pine weevils attack and kill the terminal portion of white pine, often killing 2 years of growth and at times 3 to 4 years of growth (Hastings and Godwin 1970). Each weevil attack reduces height growth by $40-60 \%$ in that year (Morrow 1965), with the overall effect on height reduction during a single rotation often approaching $10 \mathrm{ft}$ (Brace 1971). Brace further noted that injury reduced total cubic volume by $3-20 \%$ and reduced sawlog volume by $20-60 \%$. Even trees that appear to recover from weevil attacks often have serious defects associated with attacks, including compression wood (Spurr and Friend 1941), stem decay associated with white pocket rot (Ostrander and Foster 1957), and bark encased knots and wane (Brace 1971).

Growing white pine under shade greatly reduces the amount of weevil injury (Graham 1918). Shade is disadvantageous to all stages of weevil development. There are two major reasons for this; first the microenvironment is cool, thus slowing weevil development; and second, shaded leaders are of insufficient diameter to support developing weevil larvae and therefore are not attractive to egglaying females. Weevil adults show a definite preference for thick leaders. This is the reason weevils concentrate attacks on larger trees in a stand, thus compounding the problem from a wood production standpoint since these large trees are often the fastest growing individuals. Sullivan (1961) showed that leaders of 0.16 in. or less in diameter were not attacked by weevils, but attacks increased up to 0.35 in. in diameter where $80 \%$ of leaders were attacked. Such a large diameter class is rarely found in shaded stands (Sullivan 1961).
Growing white pine in shade requires a tradeoff, because shade reduces overall growth, and heavy shade can lead to tree mortality. In addition, overstory trees can create a physical barrier to understory white pine and subsequently damage leaders. The management goal should provide sufficient shade to cool the microenvironment and prevent the leaders from developing diameters which make them suitable for weevil attack yet allow in enough light for adequate growth. To sustain growth and satisfactory weevil control, specific guidelines using basal area of overstory should be developed for land managers. This study was initiated in 1973 to provide that information for young white pine stands, 5 to $10 \mathrm{ft}$ in height, growing under a predominantly oak overstory in central Wisconsin. In 1983, it was estimated that Wisconsin had 453,400 ac of white pine reproduction under hardwood overstories. Approximately, 153,600 ac of this was within the oak/hickory type (Spencer et al. 1988). Much of this white pine would benefit by proper release which could increase growth, yet maintain quality through weevil control.

\section{METHODS}

A well-stocked, 70-ac hardwood stand, composed mainly of low grade oak with some red maple and aspen, was selected in 1973 on the Black River State Forest in Wisconsin. The overstory basal area ranged from 100-120 $\mathrm{ft}^{2}$. The stand had a well-stocked natural understory, approximately 750 white pine per acre, ranging from 5 to $10 \mathrm{ft}$ in height.

Four levels of canopy removal were established based on hardwood basal area and an untreated check. The following basal area/ac (BA) overstory treatments were created: $0,30,50$, and $70 \mathrm{ft}^{2}$. Canopy trees were girdled during the winter of 1973-1974. Each treatment was replicated twice in 5- to 5.25-ac blocks.

Ten permanent $1 / 50$ th ac plots were established in each block. On each plot, all trees approximately $6 \mathrm{ft}$ tall were selected for analysis of leader growth and weevil damage, resulting in the selection of 100-210 trees per treatment. The 6-ft-tall height class was selected since it represented the majority of understory white pine in the stand. Annual leader length was measured to the nearest 0.125 in. and leader diameter to the nearest 0.0625 in. These annual measurements were made from 1974 to 1979 . In addition, pretreatment leader lengths were measured in 1974, for the years 1971-1973. Presence or absence of weevil attack(s) was recorded for sample trees.

The sample means reported in this paper for annual leader length and leader diameter from 1974-1979 were taken directly from Forest Service Interim Reports in 1976 and 1977 (Hastings 1976, Hastings and Nash 1978) and a Final Report made in 1980 (Hastings and Morse 1980). The original data were no longer available, therefore values were limited to means since no standard errors were reported.

The permanent plots were not revisited between 1979-1989 but were evaluated in 1990. Many of the tags ind1cating which plot trees were in the original $6 \mathrm{ft}$ class no longer existed. Therefore, all white pines remainıng in a plot were investigated for number and year of weevil attacks. Since successful weevil attack kills the terminal shoot and causes a crook noticeable for many years, the authors felt a reliable identification of previous weevil attacks could be made. Also recorded for all white pine in each plot was their crown class; dominant, codominant, intermediate, or suppressed. Crown class designation ignored overstory hardwoods. Any damage to understory trees by the falling of girdled overstory trees was recorded. Tree height, measured to the nearest $0.10 \mathrm{ft}$ using a telescoping measuring pole, and $\mathrm{dbh}$, measured to the nearest 0.10 in. using a diameter tape; were recorded for the two tallest white pine on each plot.

Data collected in 1990 were statistically analyzed as a split-plot design, using analysis of variance (ANOVA), significantly different means were separated by the least significant difference (LSD) method ( $P=0.05)$. Number of attacked trees was converted to percent of trees attacked on each plot. Percent data was then transformed using arcsine $-\sqrt{\%}$ and analyzed for significant differences using the LSD method. Suppressed white pine were not included when calculating percent of trees attacked per plot.

\section{RESULTS AND DISCUSSION}

In 1990, the mean number of all white pine per $1 / 50$ th ac plot were $10.4,15.1,12.7,14.5$, and 15.2 for the $0,30,50,70 \mathrm{ft}^{2} \mathrm{BA}$ and check treatments, respectively. A larger percentage of trees on the more shaded treatments were in the intermediate and suppressed categories with $85 \%$ in the $70 \mathrm{ft}^{2} \mathrm{BA}$ and check treatments and 76 , 71 , and $61 \%$ intermediate or suppressed in the 50,30 , and $0 \mathrm{ft}^{2} \mathrm{BA}$ treatments, respectively. Mortality of suppressed white pine was evident only on the check plot. Also noted, though not measured, was the larger diameter of the remaining oak in the 30 and $50 \mathrm{ft}^{2} \mathrm{BA}$ treatments.

By 1990, significant differences in percent of trees attacked by weevils were evident among treatments $(P<$ 
Table 1. Percent of dominant, codominant, and intermediate white pine on each treatment with at least one white pine weevil attack which occurred between 1974 and 1989, and mean tree height and mean tree diameter of the two tallest white pine on each treatment in 1990 on the Black River State Forest, WI. (Treatments (TRT) were basal area/ac (BA) of overstory maintained. Check treatment had 100-120 $\mathbf{f t}^{\mathbf{2}}$ BA.)

\begin{tabular}{cccc}
\hline $\begin{array}{c}\text { Treatment } \\
(\mathrm{BA})\end{array}$ & $\begin{array}{c}\text { Trees } \\
\text { attacked } \\
\% \pm \mathrm{SD}^{\mathrm{ab}}\end{array}$ & $\begin{array}{c}\text { Tree } \\
\text { height } \\
\mathrm{ft} \pm \mathrm{SD}^{\mathrm{a}}\end{array}$ & $\begin{array}{c}\text { Tree } \\
\text { diameter } \\
\text { in. } \pm \mathrm{SD}^{\mathrm{a}}\end{array}$ \\
\hline & & $\begin{array}{c}\mathrm{N}=40 \\
\text { Trees } / \mathrm{TRT}\end{array}$ & $\begin{array}{c}\mathrm{N}=40 \\
\text { Trees } / \mathrm{TRT}\end{array}$ \\
$\mathbf{0 \mathrm { ft } ^ { 2 }}$ & $68.7 \pm 5.1 \mathrm{a}$ & $33.8 \pm 0.8 \mathrm{ab}$ & $7.0 \pm 0.3 \mathrm{a}$ \\
$30 \mathrm{ft}^{2}$ & $37.8 \pm 3.6 \mathrm{~b}$ & $35.3 \pm 0.6 \mathrm{a}$ & $6.5 \pm 0.2 \mathrm{a}$ \\
$50 \mathrm{ft}^{2}$ & $15.4 \pm 3.8 \mathrm{c}$ & $30.3 \pm 1.0 \mathrm{c}$ & $4.7 \pm 0.2 \mathrm{~b}$ \\
$70 \mathrm{ft}^{2}$ & $5.7 \pm 1.7 \mathrm{~d}$ & $30.6 \pm 0.9 \mathrm{c}$ & $4.1 \pm 0.2 \mathrm{bc}$ \\
$\mathrm{Check}^{2}$ & $4.2 \pm 2.7 \mathrm{~d}$ & $31.8 \pm 0.8 \mathrm{bc}$ & $4.0 \pm 0.2 \mathrm{c}$ \\
\hline
\end{tabular}

Means within a column followed by the same letter are not significantly different, LSD method $(P=$ 0 05).

bercent data transformed using arcsine- $\sqrt{\%}$ before testing for significant differences.

0.001) (Table 1). The $0 \mathrm{ft}^{2} \mathrm{BA}$ treatment had the largest percent of trees attacked, followed in order by the 30,50 , 70 , and check treatments. No significant differences were found between the $70 \mathrm{ft}^{2} \mathrm{BA}$ treatment and the check. Further, those treatments with the highest percent weevil attacked trees also had trees which were attacked more than one time. For the $0 \mathrm{ft}^{2} \mathrm{BA}$ treatment, $23 \%$ were weevil attacked three or more times, $32 \%$ twice, and $45 \%$ once. For the $30 \mathrm{ft}^{2} \mathrm{BA}$ treatment, $12 \%$ were weevil attacked three times, $39 \%$ twice, and $49 \%$ once. For the 50 $\mathrm{ft}^{2}$ BA treatment, $5 \%$ were attacked three times, $18 \%$ twice, and $77 \%$ once. For the $70 \mathrm{ft}^{2} \mathrm{BA}$ and check treatments, only single attacks were observed. Little damage caused by girdled trees falling onto understory pine was noted in any of the treatments.

Approximately 93, 165, 265, 205, and 215 unattacked trees per acre, excluding suppressed individuals, were present on the $0,30,50,70 \mathrm{ft}^{2} \mathrm{BA}$ and check treatments, respectively. These values will undoubtedly fluctuate widely on other sites due to differences in initial stocking. However, they do provide a useful comparison between treatments in this study.

Release did impact leader growth, with growth for the 6-yr-period following treatment (1974-79) being 1.98, $144,1.37,1.03$, and 0.91 times pretreatment leader growth for the 0,30 , 50,70 and check treatments, respectwely (Hastings and Morse 1980). Despite this, mean tree height in 1990 , was actually greater for the $30 \mathrm{ft}^{2} \mathrm{BA}$ treatment than for the $0 \mathrm{ft}^{2}$ BA treatment, though not significantly (Table 1 ). This may have occurred because of the height loss from the more frequent weevil attacks in the $0 \mathrm{ft}^{2} \mathrm{BA}$ treatment. Another reason may have been the difference in sampling schemes since many trees were sampled in the 1974-1979 period while only the two tallest trees per plot were measured in 1990. In 1990, total tree heights for the
$50,70 \mathrm{ft}^{2} \mathrm{BA}$, and check treatments were less than either the 0 or $30 \mathrm{ft}^{2} \mathrm{BA}$ treatments. In addition, mean dbh measured in 1990 for 0 and $30 \mathrm{ft}^{2} \mathrm{BA}$ treatments was significantly greater than for the other treatments (Table 1). Therefore, it was concluded that growth was more rapid in the 0 and 30 $\mathrm{ft}^{2} \mathrm{BA}$ treatments, which allowed in more sunlight.

Leader diameters, measured from 1974 to 1979 , also increased at a greater rate in those treatments which allowed more sun to reach the understory pine (Table 2). Leader diameter growth response appeared to be quite rapid as differences appeared to be evident the summer following girdling of trees in 1974. As noted earlier, Sullivan (1961) found leader diameter to be a major factor in weevil success. He reported that leaders with diameters less than 0.16 in. were not attractive to weevils and even if attacked they did not provide sufficient food resources to produce weevil adults. Sullivan reported that attacks increased as leader diameter increased up to 0.35 in. where $80 \%$ of trees were weevil attacked. Therefore, in this study, within a few years of overstory removal, leaders in the $0 \mathrm{ft}^{2}$ and $30 \mathrm{ft}^{2} \mathrm{BA}$ treatments had increased to diameters sufficient to support weevils.

Despite the sufficient leader diameters, little weevil attack was noted within any treatments by 1979 (Hastings and Morse 1980). Backdating at-

Table 2. Mean leader diameters for each treatment, 1974-79. (Treatments were basal area/ac (BA) of overstory maintained. Check treatment had 100-120 BA. Sample size $(N)$ ranged from 104 to 201 trees per treatment. Study conducted on the Black River State Forest, WI.)

\begin{tabular}{cccccccr}
\hline \multirow{2}{*}{$\begin{array}{c}\text { Treatment } \\
(\mathrm{BA})\end{array}$} & $\mathrm{N}$ & 1974 & 1975 & 1976 & 1977 & 1978 & 1979 \\
\hline & 106 & 0.17 & 0.19 & 0.21 & 0.22 & 0.30 & 0.26 \\
$0 \mathrm{ft}^{2}$ & 201 & 0.13 & 0.18 & 0.16 & 0.15 & 0.23 & 0.19 \\
$30 \mathrm{ft}^{2}$ & 104 & 0.14 & 0.15 & 0.16 & 0.14 & 0.19 & 0.19 \\
$50 \mathrm{ft}^{2}$ & 200 & 0.08 & 0.13 & 0.14 & 0.11 & 0.16 & 0.13 \\
$70 \mathrm{ft}^{2}$ & 156 & 0.08 & 0.12 & 0.13 & 0.08 & 0.14 & 0.12 \\
\hline Check & & & & & & &
\end{tabular}
white pines grow taller they do not tacks in 1990 indicated that the major1ty of weevil attacks occurred after 1979 (Fig. 1). Studies have shown that weevil populations build slowly in stands (Dixon and Houseweart 1982). One reason for this may be the weevils' limited capability to disperse over large distances. Studies on weevil movement have indicated that the vast majority of weevils do not move far (Wallace and Sullivan 1985). Harman and Kulman (1967) and Harman (1975) observed that most weevils stayed within 33 to $180 \mathrm{ft}$ of a release point, though a few individuals did move as far as $980 \mathrm{ft}$. In this study, weevil attacks peaked in the mid-1980s (Fig. 1) and then declined. This decline may have been a natural fluctuation in weevil numbers, or it may have been caused by the effects of increased shading as the released white pine began to fully utilize the site and to shade and cool the understory microclimate, thus creating conditions once again unfavorable to weevil survival. It is unlikely that the white pine had simply outgrown the weevils since as outgrow weevil attacks (Ostrander 1957), with attacks recorded in trees taller than $60 \mathrm{ft}$.

The heavily shaded treatments $(70$ $\mathrm{ft}^{2} \mathrm{BA}$ and check) were affected only slightly by weevils, but did not have adequate growth of the understory white pine. Based on this, a recommendation of approximately $50 \mathrm{ft}^{2} \mathrm{BA}$ overstory should provide an appropriate compromise to provide a maximum number of unattacked pine as potential crop trees. If more rapid growth is desired, then basal areas approaching $30 \mathrm{ft}^{2}$ may be adequate, though it may result in moderate levels of weevil attacks. Maintaining an overstory has one further advantage in that overstory presence has been shown to reduce the amount of blister rust impacting white pine (Van Arsdel 1962). These basal area recommendations should be reliable for releasing understory white pine growing under predominantly oak overstories in central Wisconsin. Unfortunately, since basal area is not an ideal measurement of shading, these results should not be extrapolated to other stands outside 


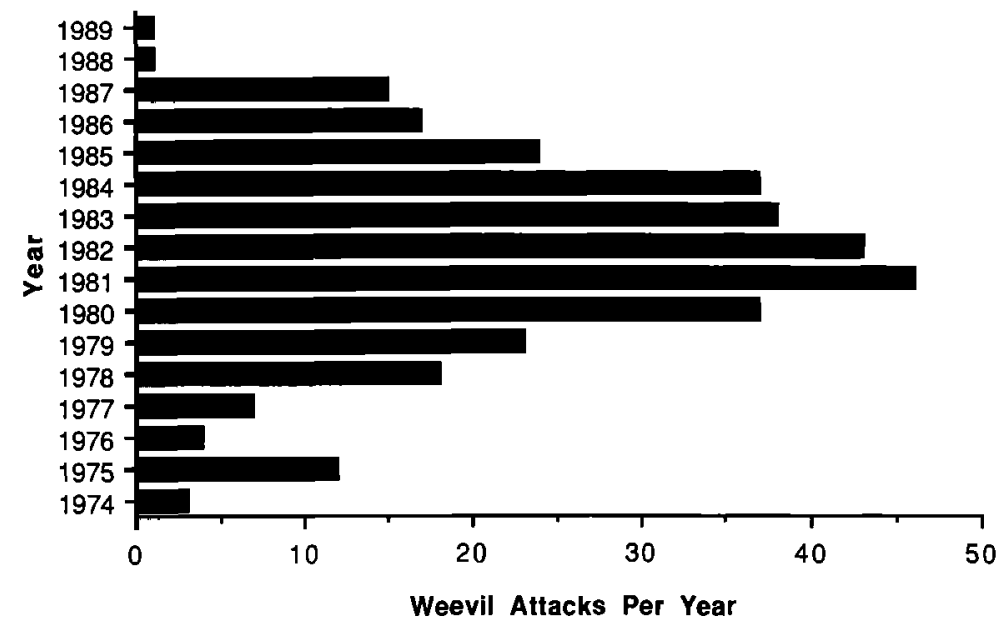

Fig. 1. Total number of white pine attacked by white pine weevil each year on $801 / 50$ th-ac plots surveyed within all overstory thinning treatments following a 1973-74 release or partial release of understory white pine on the Black River State Forest, WI. Weevil attacks occurring on two untreated check blocks were not included.

the geographic area of this study or this specific habitat type without some concern. Ideally, a measurement of crown closure or light penetration would have helped qualify these results.

Studies in other locations and forest types need to be done to confirm these results and obtain more refined basal area recommendations for specific locations and forest types. These studies probably do not need to be long term, but could be shortened by not measuring number of weevil attacks over time, but rather leader diameter response to specific treatments. This measurement appears to be a sensitive measure of white pine risk of weevil attack.

\section{MANAGEMENT IMPLICATIONS}

To obtain adequate growth rates while maintaining low levels of white pine attacks and mechanical damage to understory white pine, girdling of overstory trees is a viable option. This study indicated that little if any resultant damage occurred to white pines from the dead overstory oak if the girdling was done when the white pine were 5 to $10 \mathrm{ft}$ tall. The removal of overstory trees does not have to be accomplished by girdling. However, logging should be low impact since a well-stocked, undamaged understory will result in a higher number of potential crop trees and a more heavily shaded understory which could result in a cooler soil microclimate less conducive to weevil survival. In central Wisconsin, maintaining 30 to $50 \mathrm{ft}^{2} \mathrm{BA}$ of oak overstory should result in managable levels of white pine weevil damage. In other locations and habitat types, the overstory basal area to be maintained may need to be further investigated to optimize growth while preventing weevil attacks. Unfortunately, a second release may be required when white pine leaders begin to contact the remaining oak overstory, probably in $10-15$ years. Removal of heavily weevil-attacked white pines, which will likely be the largest individuals, also should be done during this operation.

From a wildlife standpoint, the initial thinning of the oak should increase diameter growth, crown expansion, and mast production of the remaining overstory trees. Girdling also will produce large numbers of potential snag trees.

The release of white pine in the understory may become a critical issue in the Lake States with the impending arrival of gypsy moth. Many of the present poor quality oak stands will be preferred by gypsy moth. Studies have indicated that gypsy moth larvae readily move to and feed heavily on understory white pine when the pine are growing under an oak overstory (Brown et al. 1988), while pine growing as a component of the overstory are not as likely to be fed on by gypsy moth. Further, Brown and others reported that heavily defoliated understory pines were likely to suffer mortality. Therefore, proper release of white pine stands at this time, which is perhaps $10-15$ years prior to the likely initial heavy wave of gypsy moth in Wisconsin, would not only produce large numbers of high quality white pine because of low levels of white pine weevil damage, but also play a role in producing stands more resistant to gypsy moth defoliation. $\square$

\section{LITERATURE CITED}

BraCE, L.G. 1971. Effects of white pine weevil damage on tree height, volume, lumber recovery and lumber value in eastern white pine Can. For. Serv. Publ. No. 1303. 33 p.

Brown, J.H., V.B. Cruickshank, W.P. Gould, AND T.P. HusBand. 1988. Impact of gypsy moth defoliation in stands containing white pine. North J. Appl. For. 5:108-111.

Curtis, J.T. 1959. The vegetation of Wisconsin Univ. Wis. Press, Madison. $657 \mathrm{p}$.

Dixon, W.N., and M.R. Houseweart. 1982. Life tables of the white pine weevil, Pissodes strobt, in central Maine. Environ. Entomol. 11:555564

Graham, S.A. 1918. The white-pine weevil and its relation to second-growth white pine. J. For 16:192-202.

HaRMaN, D.M. 1975. Movement of individually marked white pine weevils, Pissodes strobi. Environ. Entomol. 4:120-124.

Harman, D.M., and H.M. Kulman. 1967. Flight and dispersal of the white-pine weevil. J. Econ Entomol. 60:1682-1687.

Hastings, A.R. 1976. Evaluating the effect of release cuttings on white pine weevil infestation, the Black River State Forest, Wisconsin. USDA For. Serv. Interim Rep. S-7-76. 4 p.

Hastings, A.R., and P.A. Godwin. 1970. Whitepine weevil. USDA For. Serv. For. Pest Leafl 21. $7 \mathrm{p}$.

HaStings, A.R., and M.R. NASH. 1978. Evaluating the effect of overstory cutting on the inc1dence of the white pine weevil Pissodes strob (Peck). USDA For. Serv. Eval. Rep. S-2-78. $4 \mathrm{p}$

HASTINGS, A.R., AND F. Morse. 1980. Evaluation of a release cutting effect on understory white pine height growth and incidence of weevl damage, Black River State Forest, Wisconsin 1980. USDA For. Serv. 16 p. (unpubl.)

MorRow, R.R. 1965. Height loss from white pine weevil. J. For. 63:201-203.

OSTRANDER, M.D. 1957. Weevil attacks apparently unrelated to height of eastern white pine USDA For. Serv. Northeast. For. Exp. Stn. For Res. Note 67. 2 p.

Ostrander, M.D., and C.H. Foster. 1957. Weevil-red rot associations in eastern white pine USDA For. Serv. Northeast. For. Exp. Stn. For Res. Note 68. 2 p.

SPENCER, J.S., W.B. SMItH, J.T. HAHN, AND G K RAILE. 1988. Wisconsin's fourth forest inventory, 1983. USDA For. Serv. Res. Bull. NC-107 $158 \mathrm{p}$

SPURR, S.H., AND R.B. Frrend. 1941. Compression wood in weeviled northern white pine J For. 39:1005-1006.

Sullivan, C.R. 1961. The effect of weather and the physical attributes of white pine leaders on the behavior and survival of the white pine weevil, Pissodes strobi Peck, in mixed stands Can. Entomol. 93:721-741.

VAN ARSDEL, E.P. 1962. Some forest overstory effects on microclimate and related white pine blister rust spread. USDA For. Serv. Tech Note LS-42. 2 p.

Wallace, D.R., and C.R. Sullivan. 1985. The white pine weevil, Pissodes strobi (Coleoptera curculionidae): A review emphasizing behavior and development in relation to physical factors Proc. Entomol. Soc. Ontario 116:39-62. 